\title{
Financial digitalization and its implication on jobs market structure
}

\author{
Narcisa Roxana Moşteanu \\ Batoul Modarress Fathi \\ Department of Business Administration \\ American University of Malta, Malta
}

\section{Keywords}

Finance digitalization, workforce qualifications, digital education, new job market structure.

\begin{abstract}
Finance digitalization and digital transformation have become the most commonly used words in the last decade, but especially in recent years. The present paper emphasizes that, in order to remain competitive and achieve market longevity, organizational structures and financial services must keep up with the digital transformation. Improving the performance but also the survival of institutions is related to the adoption of innovation and the adoption of digital changes. This article aims to show how digital transformation and the adoption of new technologies have changed the approach of the workplace, the way of doing business and redefined the parameters of the financial products and services offered. The research finds out that the main impediments encountered in digitizing the activity of institutions is the efficient storage and utilization of the database, as well as the qualification and speed of adapting the workforce to the new requirements regarding the provision of innovative administrative and financial products and services through digital technology. In the same line, using macroeconomic indicators from different regions of Europe, related to the movements and new developments of the labor market, economic and social progress trend, the present work paper comes to sound an alarm signal for a new economic and technological education policy approach. The paper underlines the movements of the labor market and the possible solutions to redirect the specialization curriculums in order to equip people with those qualifications and skills which will make them employable on the current digitalized business environment.
\end{abstract}

\section{Introduction}

Digital solutions and new technologies offer great potential to overcome massive development challenges and can contribute to achieving the goal of universal access to all business services (Moshirian, 2011). Digitization and digital business promise a universe of applications and digitalized assets that are expected to work together to allow rapid development of new capabilities that will give competitive advantage (Moşteanu, 2019a). To remain competitive and achieve longevity in the market, financial services has to keep up with digital transformation. The survival of financial institutions is connected with the adoption of innovation, and embracing digital changes, to improve the efficiency and performance within the organization (Scardovi, 2017). Digital transformation and new technology adoption have changed the way of doing business and channels that offer banking and financial products and services are more intuitive and trustworthy (Mohamed and Ali, 2019). The present work paper purpose is to find out the main impediments encountered in digitizing the activity of institutions, which are the qualification or educational challenges to prepare the workforce for the new job market structure aligned with the new requirements coming from introduction and implementation of digital technology. The reconstruction of organizations design using actual financial technologies imply new educational specializations and developing new skills and competences to fulfill de challenges of different and new job requirements.

\section{Literature review}

Educational institutions and governing practices are increasingly augmented with digital database technologies that function as new kinds of policy instruments. Digital database technologies facilitate the generation, calculation, and circulation of the data required to (Williamson, 2016; Moşteanu et.al., 2020a, b) develop new educational curriculum to prepare people for successful employment in a Finance Digital era. Digital systems are becoming more and more used, representing a much faster, cheaper, and safer way when it comes to financial transactions. Access to modern telecommunications systems is a priority in all countries around the world, as in their evolution, financial and banking systems implement, use and 
encourage online services for domestic and international financial transfers (Moşteanu and Faccia, 2020). Digitization and digital transformation have become the most commonly used words in the last decade, but especially in recent years. There is an excess of definitions of this term, used to describe the offline-toonline migration of commercial operations and businesses, including those found in many published research works (Moşteanu, 2020a). Contemporaneous economists defined digitalization as the realignment of, or new investment in, advanced technology and business models to more effectively engage digital customers at every touchpoint in the customer experience lifecycle (Solis, et.al., 2014).

The new demands of the labor market require more and more new skills. In this regard, new training companies are developing interactive educational programs for digital instruction for all those who are interested in learning online or at a distance, or developing educationally regarding new digital technologies, so that they can make decisions related to improving work performance. Digital education introduces a healthy corrective to exaggerated techno-optimism or techno-pessimism (Thomas, 2011). Now everything becomes digital: tools, literacy, solutions, data systems, education, generation, and types of markets. Institutional reforms in labor relations are carried out in the digital economy both in the content and in the form. New technologies restructure subject-object economic relations and change qualitatively a business model based on special algorithms application (Vovchenko, et.al., 2017). In this respect organizations and educational system is better to redesign their structure, work processes, and services provided in order to face the challenges of customers - workforce. So rapid are the developments, in fact, that while the digitization of everything has become a hallmark of tech's promise of individual and business empowerment, it has also begun to prompt anxiety, including among workers who worry about their future in a world of brilliant machines (Muro, et.al., 2017; Moşteanu, 2020b; Moşteanu and Galea 2020; Moşteanu, 2020c).

Currently, the European Commission is promoting various initiatives aimed at increasing training in digital skills for the workforce and for consumers; modernizing education across the European Union; harnessing digital technologies for learning and for the recognition and validation of skills; and anticipating and analyzing skills needs (European Commission, 2020). In the digital age, organizations need to reinvent themselves at a structural level and to become agiler (Moşteanu, 2019c). Digital maturity of human resources management implies a shift from traditional paradigm on the workplace towards engagement, learning, and development of employees and search for talent (Mihalcea, 2017; Moşteanu, 2019b; Moşteanu, 2011a).

\section{Research methodology}

The present work paper is exploratory research, based on investigative techniques. It is fundamental and qualitative research, which aims to identify the main impediments encountered in digitizing the activity of institutions, as well as the necessity of adapting the qualification and speed of adapting the workforce to the new requirements regarding the provision of innovative administrative and financial products and services through digital technology. The paper presents the new approach of finance and the necessity to review and adapt the management and supervision of any organization to compete with new digital technologies. The research paper uses macroeconomic indicators from different regions of Europe, related to the movements and new developments of the labor market, economic and social progress trend.

\section{Analyze and findings}

The digital revolution, or third industrial revolution, occurred in the second half of the $20^{\text {th }}$ century (Scholz, 2013). The consequence of this was the automation of work technologies devices, with the insertion of computers, the massive use of the Internet, the development of microprocessors and high-tech communications impacting on society in a universal way, modifying the ways of life of ordinary citizens (Scribano and Lisdero, 2019; Beck, et.al., 1994). Digital transformation has come into wide use in contemporary business media to signify the transformational or disruptive implications of digital technologies for businesses (Nambisan, et.al., 2019) (new business models, new types of products and services, new types of customer experiences) (Boulton, 2018; Boutetiere and Reich, (2018) and more broadly, to indicate how existing companies may need to radically transform themselves to succeed in the emerging digital world (McAfee and Brynjolfsson, 2017; Brynjolfsson, 2011; Rogers, 2016; Venkatraman, 
2017). Digital transformation affects all businesses; however, SMEs are giving more attention in offering new digital solutions (Ayandibu and Houghton, 2017).

To tackle the digital skills gap, significant investments are needed. In the current European Union's budget, the Commission proposes coherent and comprehensive support for building up the digital skills needed to support reskilling and upskilling in Europe for a successful digital transformation. Different funds will target different skills needs. The Digital Europe Program with a budget of $€ 700$ million will expand the digital talent pool with around 256,000 people who will be able to deploy the latest technology in business throughout Europe. It will focus on three types of actions (European Commission, 2020):

Master's Programs in cutting-edge digital technologies developed together with European Union excellence centers in artificial intelligence, cyber and high-performance computing. The aim is to offer 160 new master programs training 80,000 digital specialists (Information and Communication Technologies skills).

Figure no.1. Components of ICT (Information and Communication Technology)

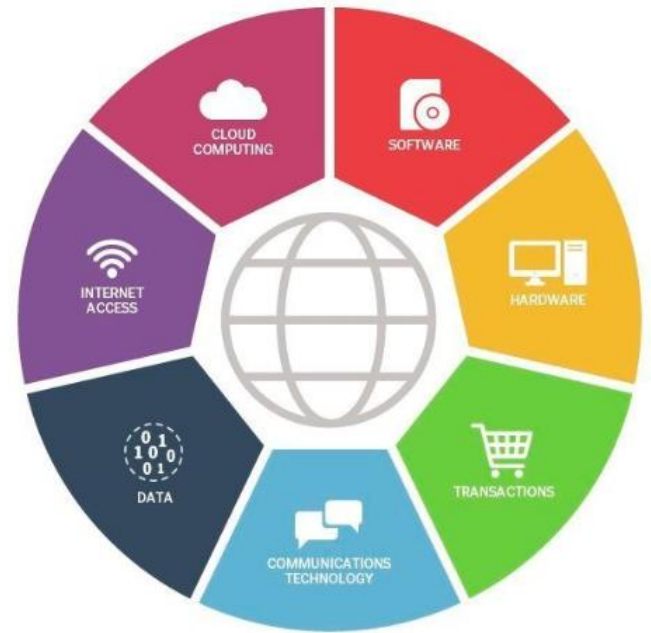

Source of picture: https:// searchcio.techtarget.com/definition/ICT-information-and-communicationstechnology-or-technologies

Short-term specialized training courses in advanced digital technologies for around 150,000 job seekers and employed people especially in SMEs. The aim is to equip them with the competences that will enable the deployment of digital technologies across all sectors of the economy.

35,000 job placements in companies or research centers where advanced digital technologies are developed or used. The aim is to give people the opportunity to learn specialists' skills working with the latest available technologies.

In order to develop The Digital Europe Program, European Commission conducted a research for the deployment of innovative digital technologies in five key areas: Supercomputing; Artificial Intelligence; Cybersecurity; advanced digital skills; and ensuring a wide use of these digital technologies across the economy and society in line with Europe's ambitious sustainability goals and values. To see the real financial implications and the number of new job structures, the survey was focused on (European Commission, 2020):

Better understanding of the potential level of demand for the different activities that are proposed under Digital Europe.

Understanding stakeholders' opinions and interests with regards to the priorities set out for the strategic objectives of the digitalization.

Obtaining the information needed in view of implementation choices and of a timely preparation of the work programs to face the challenges of the digital era. 
Figure no.2. Group of respondents (European Commission, 2019)

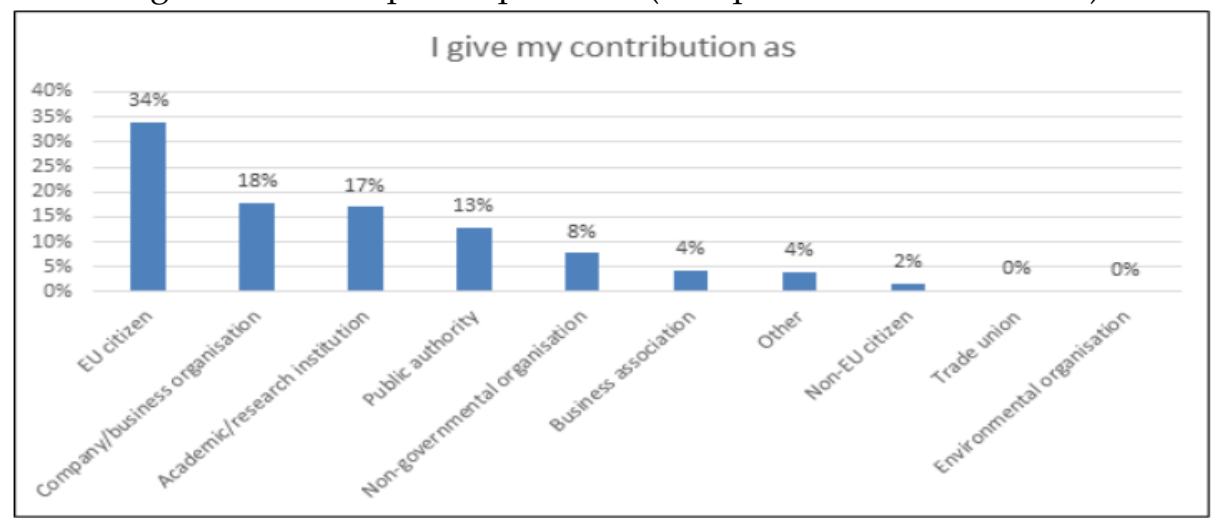

There were 960 respondents from all 28 European Union countries. 326 replies from European Union citizens, 171 from companies and business organizations, 41 from business associations, 124 from public sector entities, and 163 from academic and research institutions as well as several other groups.

The largest number of responses came from Germany (13\%), Italy (11\%), Spain (8\%), Belgium (7\%), the Netherlands (7\%), Romania (6\%) and France (6\%) totaling 56\% of responses.

Figure no.3. Respondents per country of origin (European Commission, 2019)

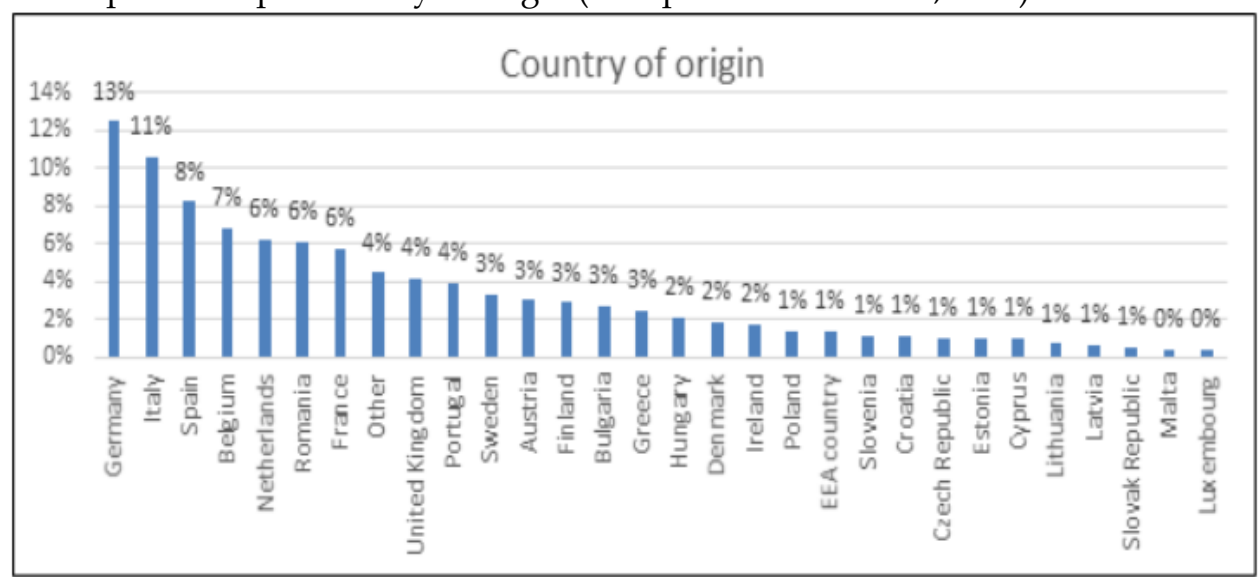

The results indicate strong support for the priorities set out in the Digital Europe Program with more than $80 \%$ of the respondents agreeing with the priorities across the main objectives.

On the question Do you agree that the European Union should support member states in improving for deployment of innovative digital technologies? For Supercomputing: $59 \%$ completely agree and $24 \%$ partially agree; for Artificial Intelligence - $64 \%$ completely agree and $24 \%$ partially agree; for Cybersecurity $64 \%$ completely agree and $22 \%$ partially agree; for Advanced digital skills $-74 \%$ completely agree and $16 \%$ partially agree; and for ensuring a wide use of these digital technologies across the economy and society: - $62 \%$ completely agree and $24 \%$ partially agree. These responses transmit a real concern of citizens for their job stability, business for their continuity, academics and researchers for a new practical approach of the digital changes.

Respondents were also asked to indicate how important they viewed European Union support for a range of areas where new digital technologies could be deployed with a high impact. The results reveal a solid encouragement for developing the digital technologies and their use in creating a clean planet (70.5\% - very important), the digital transformation of learning and education (62.5\% - very important) and a more trustful and safer internet (54.9\% - very important). On the other hand, the responses indicate less support for the uptake of blockchain (32.1\% - very important). 


\section{Conclusions}

A strong digital economy is vital for innovation, economic growth, job development, and country competitiveness (Moşteanu, 2011b, c). The spread of digital is having a massive impact on the labor market and the type of skills needed in the economy and society (European Commission, 2020).

It is changing the structure of employment, leading to the automation of routine tasks and to the creation of new and different types of jobs.

It is leading to the need for more skilled ICT professionals in all sectors of the economy. There are already hundreds of thousands of unfilled vacancies for ICT professionals in Europe.

It is leading to the need for digital skills for nearly all jobs where ICT complements existing tasks. Careers such as engineering, accountancy, nursing, medicine, art, architecture, and many more - require increasing levels of digital skills.

It changes the way we learn by fostering online communities, by enabling personalized learning experiences, by supporting the development of soft skills such as problem-solving, collaboration and creativity, and making learning fun.

It is leading to the need for every citizen to have at least basic digital skills in order to live, work, learn and participate in the modern society.

In 2020 the European labor market is projected to grow by more than 670,000 new jobs, but it could absorb another 756,000 ICT practitioners if only enough supply were in sight (Hüsing, et.al., 2015). During the last 5 years, in Europe, organizations (except financial sectors) employed more than 20 ICT specialists (Eurostat, (2020). Meanwhile, because many companies started to implement and use digital systems, many job places were reduced. Some certain activities are now done through innovative technologies, which imply requalification and gaining new skills and competences. If 10 years ago digitalization was not a concern, currently a demand development for new skills and qualifications is an actual market outcome.

The paper finds out that the main challenges encountered in digitizing the activity of institutions came out from the reconstruction of organizations design which started to use actual financial technologies, and this entails new educational specializations and developing new skills and competences to fulfill de challenges of different and new job requirements. The digital technologies facilitate the generation, calculation and circulation of the data required to (Williamson, 2016) develop new business processes to prepare organizations for successful integration in a digitalized era, but more than this, can be a very useful tool to help managing the risk of disaster, during all its steps, such as: identifying and measuring, preventing and preparing for recovering (Moşteanu, 2020d; 2011d). In order to keep up with the developments of new technologies, especially digitalization, in all economic sectors, a collaboration between the academic environment, the private sector, and public institutions with responsibilities in employment policy seems more than ever needed (Moşteanu, 2020e). Universities are encouraged to collaborate with the business sectors, to define together the new competencies and knowledge necessary to develop appropriate specializations, which will equip graduate students with the qualifications necessary for the demands of the new labor market. Digitalization and its new skills and competences come to improve the labor policy too, to avoid an increase in the unemployment rate. In 2010, the International Labor Organization has carried out a review of the International Standard Classification of Occupations (ISCO-88) in order to provide a more efficient classification that can be used by all countries at the next round of population censuses, such as and within national employment services and other customer-oriented applications (Ministry of Labor and Social Protection, 2010). This Standard Classification of Occupations is better to be amended according to the new job market demands because of the implementation of digital systems in almost all economic sectors, public or private.

\section{Limitations and direction for future research}

The present research paper presents some limitations in terms of data related to the updated descriptions of job requirements for new functions, represented a challenge in designing the integration of support functions linked to digital systems. The author intends to develop a further research, based on more detailed information and data correlated to the skills, competences, and activities required for developing and implementing digital systems in any organizational structures, as well as the reallocation and requalification of employees. An important data related to the number of employees which will be 
relocated as a result of new technologies implementation, may lead to significant changes into labor policy of each country, as well.

\section{References}

Ayandibu, A.O. and Houghton, J., 2017. The role of Small and Medium Scale Enterprise in local economic development (LED). Journal of Business and Retail Management Research, 11(2). Beck, U., Giddens, A., \& Lash, S., 1994. Reflexive Modernization. Cambridge: Polity Press.

Brynjolfsson, E., 2011. ICT, innovation and the e-economy. EIB Papers 16(2), 60-76.

Boulton, C., 2018. What is Digital Transformation? A Necessary Disruption. CIO. Retrieved on December 20, 2018 from https://www.cio.com/article/3211428/digital-transformation/ what-is-digital-transformation-a-necessarydisruption.html.

Boutetiere, H., Reich, A., 2018. Unlocking Success in Digital Transformations. McKinsey Digital. Retrieved on October 17, 2018 from https://www.mckinsey.com/business-functions/organization/ our-insights/unlocking-success-indigital-transformations

European Commission, 2020. Digital Skills E Jobs. Retrieved on February 10, 2020 from https://ec.europa.eu/digitalsingle-market/en/policies/digital-skills

European Commission, 2019. Digital Europe Programme; Summary Report on the targeted consultation on the future of investment in Europe's digital economy. Retrieved on , December 17, 2019 from https://ec.europa.eu/digitalsingle-market/en/news/digital-europe-programme-summary-report-targeted-consultation-future-investmenteuropes-digital

Eurostat, 2020. Retrieved on February 18, 2020 from https://appsso.eurostat.ec.europa.eu/nui/show.do?dataset=isoc_ske_itspen2\&lang=en

Hüsing T. Korte W.B., Dashja F., 2015. E-Skillas in Europe. Trends and Forecasts for the European ICT Professional and Digital Leadership Labour Markets (2015-2020). Empirica. Retrieved from http://eskills-lead.eu/news/singleview/for-europe-a-potential-of-more-than-750000-new-ict-jobs-until-2020.html

McAfee, A., Brynjolfsson, E., 2017. Machine, Platform, Crowd: Harnessing Our Digital Future. WW Norton \& Company.

Mihalcea, A., 2017. Employer branding and talent management in the digital age. Management Dynamics in the Knowledge Economy, 5(2), 289-306.

Moshirian, F., 2011. The global financial crisis and the evolution of markets, institutions and regulation. Journal of Banking \& Finance, 35(3), 502-511.

Moşteanu, N.R., 2019a. Principles of International Finance, Banking and Taxation. Publisher: Universitara, Bucuresti, Romania.

Moşteanu, N.R., 2019b. International Financial Markets face to face with Artificial Intelligence and Digital Era. Theoretical and Applied Economics, 3(620), 123-133.

Moşteanu, N.R., 2019c. Intelligent Foreign Direct Investments to boost economic development - UAE case study. The Business \& Management Review, Vol.10, Issue 2, p.1-9

Moşteanu, N.R., 2020a. Green Sustainable Regional Development and Digital Era. In Green Buildings and Renewable Energy, Springer, pp. 181-197.

Moşteanu, N.R., 2020b. Education, qualification awareness and social civism to build and sustain a healthy and developed society. Proceedings of 28th European Biomass Conference \& Exhibition, EUBCE 2020, Marseille, France, 6 -7 July 2020.

Moşteanu, N.R., 2020c. Artificial Intelligence and Cyber Security - A Shield against Cyberattack as a Risk Business Management Tool - Case of European Countries. Quality-Access to Success Journal, 21(175), 148-156.

Moşteanu, N.R., 2020d. Management of Disaster and Business Continuity in a Digital World. International Journal of Management, 11(4), 169-177.

Moşteanu, N.R., 2020e. Finance digitalization and its impact on labor market. Technium Social Sciences Journal, 8, 598605.

Moşteanu, N.R., Faccia, A., 2020. Digital Systems and New Challenges of Financial Management - FinTech, XBRL, Blockchain and Cryptocurrencies. Quality-Access to Success Journal, 21(174), 159-166.

Moşteanu, N.R., Galea, K., 2020. Artificial Intelligence and Cyber Security - face to face with Cyberattack - a Maltese case of Risk Management approach. EcoForum. 9(2), 672-679.

Moşteanu, N.R., Faccia, A., Cavaliere, L.P.L., 2020a. Digitalization and green economy - changes of business perspectives. In Proceedings of 4 th International Conference on Cloud and Big Data Computing (ICCBDC), Liverpool, UK, August 26-28, 2020.

Moşteanu, N.R., Faccia, A., Cavaliere, L.P.L., 2020b. Disaster Management - Digitalization and Financial Resources important factors to keep the organization ongoing. In Proceedings of 4 th International Conference on Cloud and Big Data Computing (ICCBDC), Liverpool, UK, August 26-28, 2020. 
Moşteanu, N.R., Faccia, A., Cavaliere, L.P.L., Bhatia, S., 2020c. Digital technologies' implementation within financial and banking system during socio distancing restrictions - back to the future. International Journal of Advanced Research in Engineering and Technology, 11(6), 307-315.

Moşteanu, N.R., 2011a. Romania' fiscal budgetary Strategy, Quality-Access to Success, 12(2), 606-609.

Moşteanu, N.R., 2011b. Regionalization of Romania, Quality-Access to Success, 12(2), 602-605.

Moşteanu, N.R., 2011c. Influence of financial policy about the employment in Romania, Budgetary Research Review, $3(1), 3-19$.

Moşteanu, N.R., 2011d. The importance of fiscal budgetary strategy within Romanian economy, Metalurgia International, 16(12), 125-127.

Mohamed, H., Ali, H., 2019. Blockchain, Fintech and Islamic Finance. CPI books GmbH, Leck.

Muro, M., Liu, S., Whiton, J., Kulkarni, S., 2017. Digitalization and the American workforce. Think-Asia.

Nambisan, S., Wright, M., Feldman, M., 2019. The digital transformation of innovation and entrepreneurship: Progress, challenges, and key themes. Research Policy, 48(8), 103773.

Rogers, D.L., 2016. The digital transformation playbook: Rethink your business for the digital age. Columbia University Press.

Scardovi, C., 2017. Digital Transformation in Financial Services. Springer International Publishing. Retrieved from //www.springer.com/gp/book/9783319669441

Scholz, T. (Ed.), 2013. Digital Labor: The Internet as Playground and Factory. New York: Routledge.

Scribano, A., Lisdero, P. (Eds.), 2019. Digital Labour, Society and the Politics of Sensibilities. Palgrave Macmillan.

Solis, B., Li, C., Szymanski, J., 2014. The 2014 State of Digital Transformation. Altimeter Group.

Thomas, M., 2011. Digital education: Opportunities for social collaboration. Springer.

Venkatraman, V., 2017. The digital matrix: new rules for business transformation through technology. Greystone Books.

Vovchenko, N.G., Andreeva, A.V., Orobinskiy, A.S., Filippov, Y.M., 2017. Competitive advantages of financial transactions on the basis of the blockchain technology in digital economy. European Research Studies, 20(3B), 193.

Williamson, B., 2016. Digital education governance: data visualization, predictive analytics, and 'real-time' policy instruments. Journal of Education Policy, 31(2), 123-141.

Ministerul Muncii si Protectiei Sociale al Romaniei (MInisrty of Labour and Social Protection of Romania), 2010. Clasificarea Ocupatiilor (English translation: Classification of Occupations). Retrieved online on March 2, 2020 from http://www.mmuncii.ro/j33/index.php/ro/2014-domenii/munca/c-o-r 